Fig. 2 indicates that plasma clearance of hydrocortisone is markedly slowed in the case of 70 per cent hepatectomy. The residual hepatic parenchyma was therefore exposed to a greater concentration of circulating steroid for a longer period of time than controls; values $3 \mathrm{~h}$ after injection were ten times greater than controls.

It should be noted that this phenomenon must be considered when experiments utilizing an agent metabolized by the hepatic parenchyma are performed in partially hepatectomized rats.

It seems probable that TT is fully inducible in the regenerating rat liver and that the alteration of induction kinetics is caused by a prolonged exposure to steroid rather than a fundamental change in enzyme regulation.

The differences in the hydrocortisone induction of TP and TT during hepatic regeneration may reflect a relationship between their mechanisms of control and the metabolic events accompanying the preparation for cell division. These factors may also be operative in the "minimal deviation" hepatomas.

We thank Dr William D. Drucker and Miss Annamarie L. Verde for determining plasma hydrocortisone. This work was supported by grants from the US National Institutes of Health and the American Cancer Society.

George W. Teebor FredFrick F. BeCker* IrVing SeIDMaN*

Department of Pathology,

New York University School of Medicine.

Received July 31, 1967.

* Health Research Council of the City of New York.

${ }^{1}$ Pitot, H. C., and Cho, Y. S., Prog. Exp. Tumor Res., 7, 158 (1965)

${ }^{2}$ Pitot, H. C., and Heidelberger, C., Cancer Res., 24, 1085 (1964).

${ }^{3}$ Knox, W. E., and Auerbach, V. H., J. Biol. Chem., 214, 307 (1955).

4 Lin, E. C. C., and Knox, W. E., Biochim. Biophys. Acta, 26, 85 (1957).

${ }^{5}$ Seldman, I., Teebor, (*. W., and Becker, F. F., Proc. Soc. Exp. Biol. and Med., 128, 274 (1966).

'Seidman, I., Teebor, G. W., and Becker, F. F., Cancer Res. (in the press).

' Higgins, G. M., and Anderson, R. M., Arch. Pathol., 12, 186 (1931).

${ }^{8}$ Bucher, N. L. R., and Swaffield, M. N., Cancer Res., 24, 1611 (1964).

' Garren, L. D., Howell, R. R., Tomkins, G. M., and Crocco, R. M., Proc. US Nat. Acad. Sci., 52, 1121 (1964).

${ }^{10}$ Grossman, A., and Mavrides, C., J. Biol. Chem., 242, 1398 (1967).

"Silber, R. H., and Porter, C. C., J. Clin. Invest., 34, 899 (1955).

12 Peterson, R. E., Karrer, A., and Guerra, S. L., Anal. Chem., 29, 144 (1957).

${ }^{13}$ Christy, N. P., Longson, D., Horwitz, W. A., and Knight, M. M., J. Clin. Invest., $\mathbf{3 6}, 299$ (1959).

\section{Ergosterol Peroxide: a Fungal Artefact}

Although the isolation of ergosterol peroxide from the extracts of several different fungi has been reported ${ }^{1-4}$, the question of its authenticity as a metabolite in these cases does not seem to have been raised. In the present case, the peroxide was found to be present in extracts of sporophores of Piptoporus betulinus or of Daedalea quercina. These extracts, however, had been exposed to daylight for several days and the peroxide could not be detected initially in fresh extracts. Ergosterol $\left(R_{F} \mathbf{0 . 4 0}\right)$ and ergosterol peroxide $\left(R_{F} \mathbf{0} \cdot 23\right)$ were both easily detected by T.L.C. on silica using 1 per cent methanol in chloroform as eluent, characteristic intense blue-black and dark green colours, respectively, being developed after spraying with ceric ammonium nitrate and heating briefly at $100^{\circ} \mathrm{C}$. A sample of the peroxide isolated after chromatography on silicic acid was identical in all respects with a synthetic sample ${ }^{5}$.

It can be shown that, in the conversion of ergosterol to its peroxide under a slow stream of oxygen, both light and a photosensitizing substance (for example, eosin ${ }^{5}$ ) are essential. The crude brown gummy materials extracted with methanol from $P$. betulinus and $D$. quercina were each able to act as photosensitizer, and $100 \mathrm{mg}$ or more of either extract allowed complete oxygenation of ergosterol $(10 \mathrm{mg})$ in methanol (10 ml.) under an ordinary 150 watt pearl lamp in $18 \mathrm{~h}$. This photosensitizing property, which was not impaired by boiling the crude extract with acid or base, is one which is exhibited by a wide range of coloured compounds to varying degrees. (The fungal anthraquinones emodin and physcion ${ }^{6}$, for example, were found to have up to 20 per cent of the sensitizing activity of eosin, a minimum of $50 \mu \mathrm{g}$ allowing complete oxygenation of $10 \mathrm{mg}$ of ergosterol in $18 \mathrm{~h}$.) Hence, as most fungal extracts contain at least small quantities of pigments, isolated ergosterol peroxide may be, in general, an artefact rather than a natural product.

H. K. ADAM

I. M. CAMPBeli

N. J. MCCorkindale

Joint Mycology Laboratory,

Departments of Botany and Chemistry,

University of Glasgow.

Received August 21, 1967.

' Wieland, P., and Prelog, V., Helv. Chim. Acta, 30, 1028 (1947).

${ }^{2}$ Bauslaugh, G., Just, G., and Blank, F., Nature, 202, 1218 (1964).

${ }^{3}$ Tanabashi, Y., and Takahashi, T., Bull. Chem. Soc. (Japan), 39, 848 (1966).

- Clarke, S. M., and McKenzie, M., Nature, 213, 504 (1967).

' Windhus, A., and Brunken, J., Justus Liebigs Annalen der Chemie, 460, 225 (1928).

- Miller, M. W., Pfizer Handbook of Microbial Metabolites (MoGraw Hill, NY, 1961).

\section{PHYSIOLOGY}

\section{Apparent Peroxide in the Blood of Pregnant Mice}

IN previous communications ${ }^{1,2}$, it was shown that the total apparent peroxide in mice was decreased by an oral contraceptive and increased by pregnancy. The uterus, ovarian fat plus ovaries, mammary tissue and adrenals of pregnant mice each showed a significant increase, but the total amount of increased peroxide in these organs accounted for only about 6 per cent of the whole mouse increase. In a further attempt to locate the peroxide induced by pregnancy, the blood of pregnant mice was examined.

The pregnant albino hairless mice and the peroxide estimations using an anoxic box were as previously described ${ }^{2,3}$. Ten control and ten pregnant mice, initially 13 weeks old, were used for this experiment, Blood was drawn from the right ventricle of the dead mouse and weighed in a thin walled glass bulb. The glass bulb was macerated with the blood.

For the calculations of peroxide in total blood it was assumed that blood is 10 per cent of the body weight.

$\begin{array}{ccc}\text { Table 1. micromolins of PEROXIDE IN MOUSE BLOOD } \\ & \text { Mean peroxide } & \text { Peroxide/g. } \\ \text { Control } & 1.52 & 0.59 \\ \text { Pregnant } & 5.96 & 1.71 \\ & P<0.01 . & \end{array}$

As shown in Table 1 there was a significant increase of peroxide in the blood of pregnant mice and this accounted for about 73 per cent of that in the whole mouse.

MRC Radiobiological Research Council,

V. J. HorgaN

Harwell,

Didcot, Berks.

Received September 8, 1967.

${ }^{3}$ Horgan, V. J., and Philpot, J. St. L., Nature, 211, 597 (1966).

2 Horgan, V. J., and Philpot, J. St. L., Nature, 215, 526 (1967).

${ }^{3}$ Horgan, V. J., and Philpot, J. St. L., Intern. J. Radiat. Biol., 8, 165 (1964). 